\title{
Inheritance of different undertones of onion (Allium cepa L.) dry skin color and the relationship between color and adherence
}

\section{ROCH W. DORUCHOWSKI}

Department of Vegetable Breeding and Genetics, Research Institute of Vegetable Crops, ul. 22 Lipca 1/3, 96-100 Skierniewice, Poland

(Received: 2, 1985)

\begin{abstract}
The research was carried out in 1977 and 1978. The inheritance of undertones dry skin color from light straw to brown was controlled by two additive genes. The segregation ratio obtained was $15: 1$ and $11: 5$. The dry skin of a dark color (dark yellow, bronze, brown ochre, orange-brown) was stronger than the skin with a straw yellow or yellow color. Skin adherence was strictly related to its color. This was proved by statistical analysis of the correlation.
\end{abstract}

\section{INTRODUCTION}

Onion cultivars àre characterized by different dry skin colors. Bulb color is a very important practical trait. Depending on the forseen use of the onions and market demand, the International Working Group of the IBPGR proposed 9 colors of onion dry skin: 1 - white, 2 yellow, 3 - light brown, 4 - brown, 5-dark brown, 6 - red, 7 - green to chartreuse, 8 - mixed population, 9 - other.

In Western and Central Europe, most of the onion market cultivars used both for immediate consumption and for storage, have from light to dark yellow dry skin. A certain number of varieties are also cultivated for drying and pickling. For local needs, certain amounts of onions with red dry skin are also seen, especially in Czechoslovakia, Bulgaria, the USSR and Yugoslavia. Onions with dry red and fleshy inner scales are valued in countries of Asia, Africa and South America. White dry skin and pulp are valued in the varieties widely cultivated in the countries of South and Central America.

The following among the Polish cultivars have the strongest dry skin: 'Rawska', 'Sochaczewska', 'Kutnowska'. 'Warszawska' has good dry 
skin. The 'Czerniakowska' variety, produced for consumption in the autumn and early winter, has a light straw colored dry skin which is not very strong. At present the most valued in Poland onion cultivar for storage and large scale export is 'Sochaczewska'. This variety forms transverse elliptic bulbs with dark straw colored, well adhering dry skin. The qualification of size and shape of bulbs from this variety is not very satisfactory.

The aim of this study was to investigate the inheritance of undertones of dry skin color and the relationship between dry skin color and adherence.

Rieman (1931), Clarke et al. (1944), Jones and Peters o n (1952) state that the color of the dry skin is determined by several genes. Cultivars which are homozygous for yellow color have the genotype: ii $C C r r$, for red color - ii $C C R R$ and for the recessive white color - ii cc $R R$, ii cc $R r$ or ii cc rr. The dominant genes, $C$, and $R$, are necessary for color to develop. Gene $I$ is an incomplete dominant in the heterozygous stage, but all onions homozygous in respect to $I I$ are white. The subsequent studies of El-Shafie and Davis (1967) showed that intensification of the golden yellow and red dry skin colors is determined by several genes, which are inherited quantitatively. They discovered 2 new genes, $L$ and $G$. Gene $L$ determines the light yellow color, gene $G$, the golden yellow color. Their 10 year long studies have shown that onion dry skin color is determined by 5 main genes: $I, C, G$, $L$ and $R$ (each with 2 alleles), which interact and segregate independently giving ratios of: $12: 3: 1,9: 7: 9,3: 4,13: 3 . L$ and $R$ are complementary genes which determine the light red color. These 5 genes act in a specific way on the biochemical pathways leading to dry skin color.

W a lker (1923), W a lke r and Lind e g ren (1924), Link et al. (1929), Rieman (1931), Link and Walker (1933), Jones et al. (1946), W a l ker et al. (1950) think that the genes of color are also responsible for the production of substances toxic for certain pathogenic factors. Due to this, the onion varieties having yellow and red dry skin are resistant to certain diseases (e.g. antracnosis Colletotrichum circinans). W a lker (1923) showed that quercetin, which is toxic for pathogenes, occurred both in red and golden-yellow skinned onions. In addition, red scales also contained anthocyan. B r a n d w e in (1965) identified flavins, a flavin glucoside and an anthocyan glucoside.

\section{MATERIALS AND METHODS}

The materials used in this study are described in the first part of this series of papers (Dor uchowski, 1986, Table 11 and 12). The inheritance of dry skin color (Table 1) in $F_{2}$ generations (Table 11 in 
Dor u c how ski, 1986) was interpreted statistically by the $\chi^{2}$ test ( $\mathrm{S} \mathrm{r} \mathrm{b}$ and $\mathrm{O}$ we $\mathrm{n}, 1959$ ).

The relationship between color and dry skin adherence (Table 2) was determined with the $\chi^{2}$ test (significance level $\alpha=0.05$ and 0.01 ).

T a ble 1

Inheritance of onion dry skin color in $\mathrm{F}_{2}$

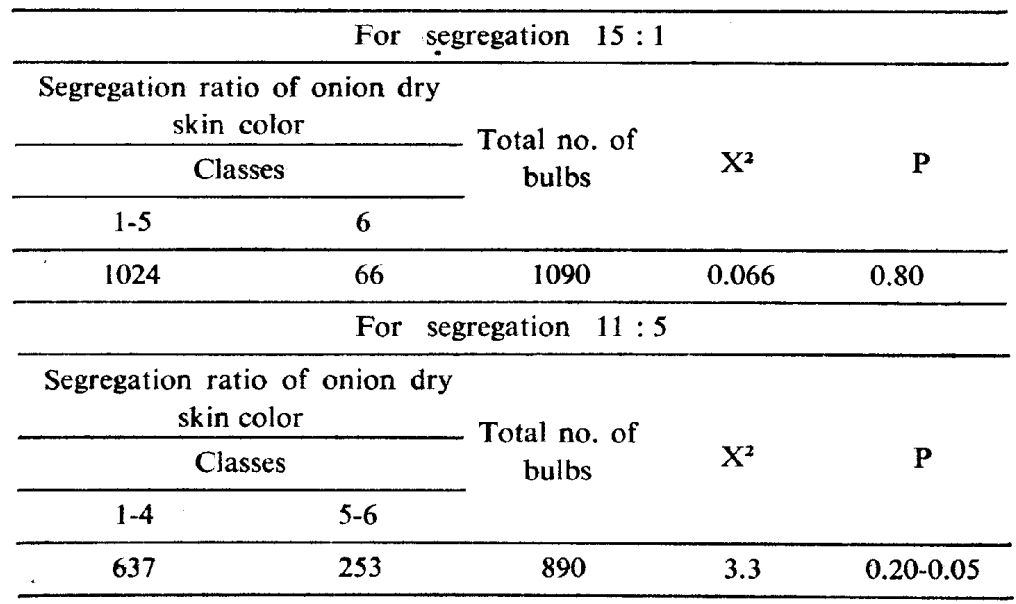

Ta b l e 2

Correlation between color and adherence of onion dry skin in $F_{2}$ hybrids

\begin{tabular}{|c|c|c|c|c|c|c|c|c|}
\hline \multicolumn{7}{|c|}{ Dry skin color } & \multirow{3}{*}{$\begin{array}{l}\text { Total no. } \\
\text { of bulbs }\end{array}$} & \multirow{3}{*}{$\mathrm{X}^{2}$} \\
\hline & & & & cla & & & & \\
\hline & & & 3 & 4 & 5 & 6 & & \\
\hline \multirow{4}{*}{ 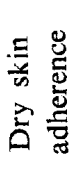 } & \multirow{4}{*}{$\begin{array}{l}\text { 总 } \\
0 \\
\frac{\pi}{0}\end{array}$} & \multirow{4}{*}{$\begin{array}{l}- \\
r\end{array}$} & 49 & 77 & 54 & 3 & 183 & \\
\hline & & & 84 & 161 & 87 & 15 & 347 & \\
\hline & & & 81 & 225 & 165 & 40 & 512 & \\
\hline & & & 214 & 464 & 306 & 58 & 1042 & $26.11^{* *}$ \\
\hline
\end{tabular}

Critical value of $\chi^{2}$ test: $(\alpha=0.05)=9.46$

\section{RESULTS AND DISCUSSION}

Six classes of color intensity were established for the segregating $F_{2}$ generation obtained by crossing lines with straw colored and brown dry skins: 1 - greenish straw colored, 2 - white, 3 - light straw colored, 4 - dark straw colored, 5 - light brown, 6 - brown. The segregation ratio of onion bulbs (Table 1) having lighter colored dry skin, that is, 
from greenish straw colored to light brown was $15: 1\left(\chi^{2}=0.066\right.$ at $P=0.80$ ). These results suggest the action of 2 additive dry skin color genes. If this hypothesis is true, the following segregation in $F_{2}$ should be expected : 1 (greenish straw colored) : 4 (light straw colored) : 6 straw colored) : 4 (light brown) : 1 (brown).

The method used for determining the color intensity of onion bulb dry skin color in the evaluation scale of 1-6, without special color charts available, was not precise enough to allow mistakes to be avoided in classifying color undertones. In addition, the modifying influence of the enviroment complicated the exactness of color determination. Therefore, the segregating $\mathrm{F}_{2}$ progeny was divided into two groups. Individuals having straw colored dry skin were assigned to the first group, those with brown skin, to the second one (Table 1 ). A segregation ratio of $11: 5$ was obtained, which was at the border of significance $\left(\chi^{2}=3.3\right.$ at $\mathrm{P}=0.20-0.05)$. The class of 11 was the result of adding the number of colorless individuals and those containing 1 or 2 genes of color classes $1,2,3,4$; the class of 5 resulted from the summing up of 3 or 4 pigmentation genes (classes 5 and 6 ). The segregation of $F_{\text {a }}$ progeny is very close to the theoretical value and allows the hypothesis to be accepted.

A significantly high interdependence was found between color and dry skin adherence $\left(\chi^{2}=26.11\right)$. The brown dry skin was thicker, stronger and adhered much better to the bulb than the light straw colored dry skin, which fell off easily. That is why more attention should be paid in breeding to these traits when selecting the components of a cross. In addition, varieties possessing dark brown, strong and well adhering dry skin should be used for large-scale onion production.

\section{CONCLUSIONS}

1. The color of onion bulb dry skin, from light straw to brown, is determined by 2 genes acting together.

2. Good dry skin adherence is correlated with its dark brown pigmentation. The darker the color, the better the adherence.

3. In order to improve by breeding the quality of dry skin, especially its good adherence, onion lines with dark brown dry skin should be employed.

\section{REFERENCES}

Brandwein B. L., 1965. The pigments in three cultivars of the common onion (Allium cepa L.). Jour. Food. Sci. 30: 680-685.

Clarke A. E., Jones H. A., Little T. M., 1944. Inheritance of bulb color in the onion. Genetics 29: 269-575. 
Doruchowski R. W., 1986. Variability and heritability of some onion (Allium cepa L.) characteristics of parental forms, $F_{1}$ hybrids and $F_{2}$ generation. Acta Agrobot. 39: 293-325.

El-Shafie M. W., Davis G. N., 1967. Inheritance of bulb color in the onion (Allium cepa L.). Hilgardia 38: 607-622.

Jones H. A., Walker J. C., Little T. M., Larson R. H., 1946. Relation of color-inhibiting factor to smudge resistance in onion. Journal of Agricultural Research 27: 259-264.

Jones H. A., Peterson C. E., 1952. Complementary factors for light red color in onions. Proc. Amer. Hort. Sci. 59: 457.

Link K. P., Dickson A. D., Walke r J. C., 1929. Further observations on the occurrence of protocatechuic acid in pigmented onion scales and their relation to disease resistance in the onion. J. Biol. Chem. 84: 719-725.

Link K. P., Walke r J, C., 1933. The isolation of catechol from pigmented orion scales and its significance in relation to disease resistance in onions. J. Biol. Chem. 100: 379-383.

Rieman G. H., 1931. Genetic factors for pigmentation in the onion and their relation to disease resistance. J. Agricult. Res. 42: 251-278.

Srb A. M., Owen R. D., 1959. Genetyka ogólna. PWRiL. Warszawa.

Wa $I$ ke r J. C., 1923. Disease resistance to onion smudge. J. Agricult. Res. 24: 1019.

Walker J. C., and Lindegren C. C., 1924. Further studies on the relation of onion scale pigmentation to disease resistance. J. Agricult. Res. 29: 507514.

Walker J. C., Owen J. H., Stakman M. A., 1950. Relative importance of phenols and volatile sulphfids in disease resistance in the onion. Phytopath. 40: 30 .

Dziedziczenie różnych odcieni barwy oraz zależność między barwą a przyleganiem suchej łuski cebuli (Allium cepa L.)

\section{Streszczenie}

Badania nad dziedziczeniem różnych odcieni barwy oraz zależnością między barwa a przyleganiem suchej łuski cebuli przeprowadzono w Zakładzie Hodowli i Genetyki Instytutu Warzywnictwa w Skierniewicach w 1977 roku. Przebadano stosunek rozszczepienia w 11 pokoleniach $F_{2}$. Stwierdzono, że barwa suchej luski cebuli o odcieniach od jasnosłomkowej do brunatnej determinowana jest 2 genami barwy działającymi addytywnie. Dobre przyleganie suchej łuski skorelowane jest z brunatną barwą İuski. Im ciemniejsza luska, tym lepsze jej przyleganie. 